\title{
Epidemiological and Molecular-Genetic Characteristics of the Measles Outbreak in Kazakhstan
}

\author{
Aygerim Zhuzzhasarova ${ }^{1 *}$ (D), Dinagul Bayesheva ${ }^{1}$ (D), Nurshay Azimbaeva ${ }^{2}$ (D), Manar Smagul ${ }^{3}$ (D), \\ Gauhar Nusupbaeva ${ }^{4}$ (D), Bayan Turdalina ${ }^{1}$ (D), Aliya Seidullayeva ${ }^{1}$ (D), Bakhytzhan Abdullaev ${ }^{5}$ (D), \\ Almagul Kushugulova 6,7 (i)
}

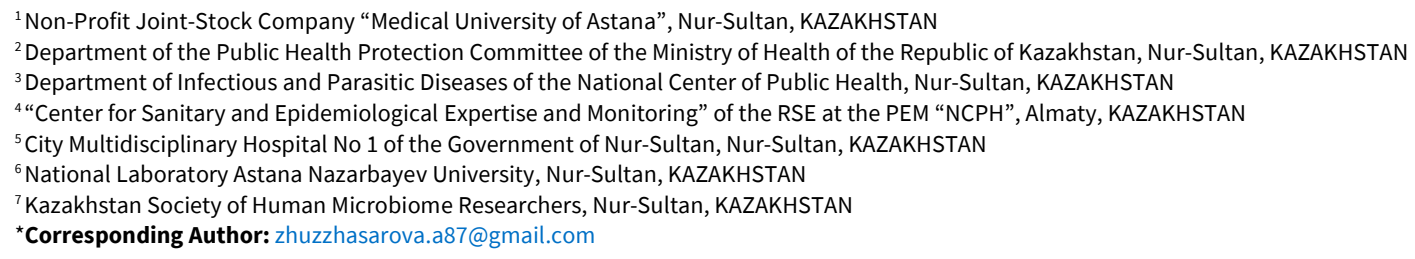

Citation: Zhuzzhasarova A, Baesheva D, Azimbaeva N, Smagul M, Nusupbaeva G, Turdalina B, Seidullayeva A, Abdullaev B, Kushugulova A. Epidemiological and Molecular-Genetic Characteristics of the Measles Outbreak in Kazakhstan. Electron J Gen Med. 2022;19(2):em350. https://doi.org/10.29333/ejgm/11549

\section{ARTICLE INFO}

Received: 31 May 2021

Accepted: 1 Dec. 2021

\begin{abstract}
Introduction: Genetic characterization of measles viruses (MVs) is an important component of laboratory surveillance of measles. In this study, a phylogenetic analysis was performed of the nucleoprotein gene sequences isolated in the Republic of Kazakhstan in 2018 year.
\end{abstract}

Objective: To study the epidemiological characteristics of measles and identify the circulating strain in the Republic of Kazakhstan during the period of increasing incidence for 36 global efforts to eliminate measles among the population.

Material and Methods: On the basis of the reference laboratory "Center for Sanitary and Epidemiological Expertise and Monitoring" of the RSE at the PEM "NCPH" genotyping of measles virus isolated from biological material (urine) from laboratory-confirmed cases was performed.

Results: According to the results of the study, it was revealed that the genotypes of the measles virus circulating in the Republic of Kazakhstan belong to two genotypes, the majority of samples $(n=16)$ belonged to the D8genotype and2 samplesto the B3 genotype/MVi/Harare.ZWE/38.09./.

Keywords: measles, Republic of Kazakhstan, children, genotyping

\section{INTRODUCTION}

Measles (rubeola) is a highly contagious disease caused by a virus in the Paramyxoviridae family. Measles virus (MV) is responsible for serious complications mainly in young children and had caused 207,500 estimated measles deaths globally in 2019 [1]. Epidemiological studies have linked measles to an increase in morbidity and mortality many years after infection. This virus attacks immune cells, causing acute suppression of the immune system. The World Health Organization (WHO) recommends a two-dose vaccination policy, with the first dose administered during the first year of life, and coverage should be maintained in at least $90-95 \%$ of the population to halt transmission. In many countries, the measles vaccine is included in the country's immunization program and is freely available to all. As recommend in general by the WHO, routine measles vaccination is included in the national immunization schedule of Kazakhstan.
In 2015, cloned and sequenced 18 samples (samples RNA) with the nucleotide sequences of the $\mathrm{COOH}$-terminal fragment of the $\mathrm{N}$ gene with a length of 450 nucleotides, found that they belonged to two genotypes, the majority of samples $(n=16)$ belonged to genotype D8 and 2 samples to genotype B3 /MVi/Harare.ZWE/38.09./.

According to phylogenetic analysis, genotype D8 are 4 dominant genetic lines, lines MVi/Villupuram.IND/03.07./D8 (12 detections), MVs/Sohar.OMN/23.12/D8 (1 detection), MVs/ Republic of Komi.RUS/35.13/D8, MVs/Pretoria.ZAF/19.09./D8. In 2017, when two samples were genotyped in the reference laboratory of the SPCSEEM, one of the viruses were identical to the $\mathrm{H} 1$ genotype strain "MVi/Hunan. $\mathrm{CHN} / 97 / 7$ " of Chinese origin. The nucleotide sequence of another identified sample when compared with the sequences of the reference strains, these viruses were almost identical to the strain of the D8 genotype "MVi/Manchester.GBR/30.94/" first isolated in Manchester (UK) in 1994.

Genotyping of the measles virus strains isolated in Kazakhstan in 2018 indicate the presence of import of 


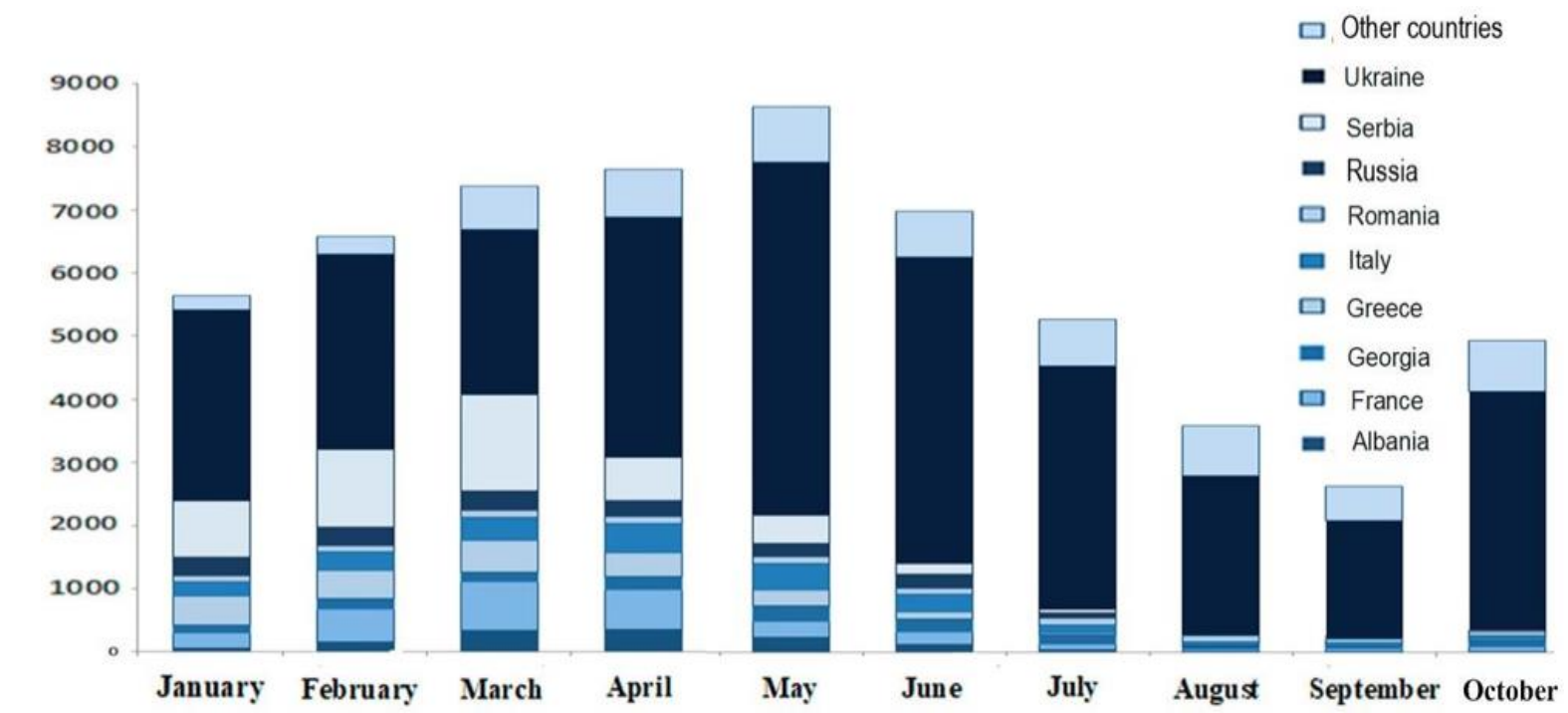

Figure 1. Cases of measles by month in the WHO European region, from January 1 to October 30, $2018(n=53,201)$

previously unregistered variants and genetic lines in Kazakhstan, as directly from regions of the globe in which indigenous transmission of measles virus is preserved. Registration of a large number of "local" cases, but cases of measles caused by the "imported" genotype of the virus, should also be alarming in terms of incomplete registration of imported cases.

Measles occupies an important place in human infectious diseases [2]. The incidence of measles before active immunization was very high and occupied first place among young children, accounting for $89-90 \%$ of airborne infections. During measles epidemics in developing African and Asian countries, the incidence rate among children aged 9 months reached 18 to $45 \%$ [3].

According to the WHO, up to 3 million cases of measles are registered annually worldwide [4], and the increase in incidence is due to both population migration and incomplete vaccination coverage. The WHO sets a target of reducing incidence by $90 \%$ and deaths by $95 \%$ in 2000 . However, measles continues to be registered worldwide Despite active immunization, due to the increase in the number of refusers from vaccination in the period from 2018 to 2020, there is a tendency to increase the incidence of measles. The priority of the preventive direction in health care, the active work of pediatricians to expand the National Immunization Calendar, and the availability of new highly effective and safe immunobiological drugs provide an opportunity to control vaccine preventable infections [5]. Due to the sharp increase in the incidence of measles, countries of the region are recommended to strengthen their outbreak monitoring activities, to continue their previous immunization programs to ensure vaccination coverage of up to $95 \%$ of the population and to strengthen vaccination promotion activities, especially among children under one-year-old, teenagers and medical staff [6]. Vaccination coverage should be maintained in at least $90-95 \%$ of the population in order to prevent endemic transmission. As recommend in general by the WHO, routine measles vaccination is included in the national immunization schedule of Kazakhstan.

The total number of measles cases in the WHO European Region from January 1 to October 30, 2018 amounted to 53,201 . Among these, $89 \%$ of all cases were registered in nine countries: Ukraine $(66 \% ; n=35,120)$, Serbia $(9.5 \% ; n=5,057)$, France $(5 \% ; n=2,787)$, Italy $(4.5 \% ; n=2,373)$, Greece $(4 \%$; $n=2,192)$, Russia (3\%; $n=1,822)$, Georgia ( $3 \% ; n=1,502)$, Albania $(3 \% ; n=1,405)$, and Romania (2\%; $n=943)$ (Figure 1). The maximum growth of the disease occursin the monthsof Apriland May, which correspondsto published data on measles seasonality $[7,8]$.

In 2018, the highest incidence rate per 1 million people was recorded in the Ukraine (795.12), followed by Serbia (578.42), Albania (481.26), and Georgia (377.99). According to the WHO European Bureau, the reasons for the outbreaks in these countries included incomplete vaccination coverage of the population, insufficient attention to measlesrisk groups (medical workers, childcare workers, etc.), irregularities in vaccination procedures, and poor epidemiological support for patients $[9,10]$.

In the Republic of Kazakhstan, 576 cases of measles were registered in the whole of 2018, including 484 cases (84\%) among children under 14 years of age. It is noted that the measles incidence rate in Kazakhstan in 2018 was 2.8 per 100 thousand people, which is $8 \%$ lower than the long-term average. The incidence ofoutbreaks in 4 regions of the country where the number of cases exceeded 1,000 patients is shown: Nur-Sultan - 22.9\% ( $n=3,181)$, Shymkent - 22.3\% ( $n=3,095)$, Mangistau $-10.3 \%(n=1,428)$ and in the Turkestan region $-8 \%$ $(n=1,110)$.

The incidence of measles in the Republic of Kazakhstan was analyzed by year from 1998 to 2019. The data obtained showed the following results: According to the data obtained, the greatest growth is noted in 2004, in which the indicator was106.4\% ( $n=16,118)$. In connection with additional immunization performed in 2005-2006, there was a subsequent decrease in the incidence rate to $0.71 \%$ in 2006 . The period from 2006 to 2014 is characterized by a period of well-being, and the level of registered patients ranged from $0.7 \%$ to $1 \%$. The year 2015 is characterized by an increase in the incidence of measles, where the overall rate was $13.54 \%(n=2,341)$, and against the background of additional immunization, a decrease in cases ranging from $0.7 \%$ to $3.1 \%$ was observed from 2016 to 2018, followed by a further increase in the incidence rates in 2018 and 2019 to $81.9 \%(n=13,312)$ (Figure 2). 


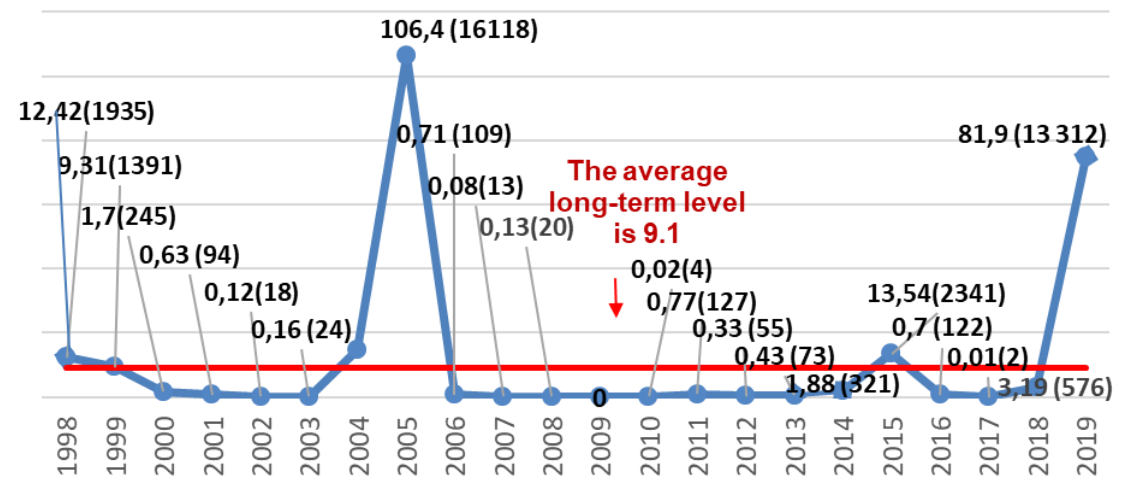

Figure 2. Long-term incidence of measles in the Republic of Kazakhstan

Measles outbreaks occurred approximately every 3-5 years, reaching between 200 and 16,000 people per year. Kazakhstan measles virus strains for this period are represented by 3 genotypes D6/MVi/Berlin.DEU/47.00/, D4/MVi/Bandarabas.IRN /05.10/2/, and D8/MVi/Villupuram.IND/03.07/.

According to the results of genotyping of strains of measles virus circulating in the Republic of Kazakhstan in the period $2006-2007$, was established endemic transmission of the virus strains of genotype D6 genetic lines /MVi/Berlin.DEU/47.00/. In 2007 the circulation of the specified genotype was interrupted, and another rise in incidence observed from 2010 to 2013, was associated with circulating strains of measles virus genotype D4 genetic lines "MVi/Bandarabas.IRN/05.10/2" of Iranian origin. Subsequently, the circulation of strains of this genetic line was also interrupted in 2013. Since the beginning of 2014, the global circulation of the measles virus has been characterized by a wide spread of strains of the virus genotype D8/MVi/Villupuram.IND/03.07/ of Indian origin. Thus, the strains of the genetic line "MVi/Villupuram.IND/03.07/[D8]", first isolated in India, were imported to Thailand in 2011, where they caused another large-scale outbreak of measles. This outbreak was accompanied by the export of the infection to a number of countries, including our Republic.

\section{MATERIALS AND METHOD}

On the basis of the reference laboratory "Center for Sanitary and Epidemiological Expertise and Monitoring" of the RSE at the PEM "NCPH" genotyping of measles virus isolated from biological material (urine) from laboratory-confirmed cases was performed. For genotyping, a standardized technique was used, based on the analysis of the nucleotide sequence of the $\mathrm{C}$ terminus of the $\mathrm{N}$ protein with a length of 450 nucleotides, the most variable region of the viral genome. Nucleotide sequences were analyzed using BioEdit Sequence, Mega 7 programs.

\section{Samples for the Study}

The material for the isolation of the virus and viral RNA was urine samples collected in time and according to the protocol recommended by WHO, from 18 patients with a clinical diagnosis of "measles". The clinical diagnosis was confirmed in the laboratory by detecting specific measles IgM in the enzyme immunoassay test system manufactured by Vector-Best, Russia. Viral RNA was isolated using a commercial Pure Link RNA Mini Kit (Life Technologies, USA) according to the manufacturer's instructions. Reverse transcription PCR (RT/PCR) was performed with using primers MeV216, MeV214, MeV217, commercial SuperScript ${ }^{\circledR}$ III One - Step RT-PCR Kit System with Platinum $^{\circledast}$ Taq DNA Polymerase (Life Technologies, USA). DNA electrophoresis was performed using a commercial set of reagents for electrophoretic detection of amplification products in agarose gel "EF" - 200 (AmpliSens, Russia) in $1.7 \%$ agarose gel with a trisborate buffer of concentrated ethidium bromide. A commercial Gel Extraction Kit (Life Technologies, USA) was used to extract DNA from the gel. The concentration of purified DNA was measured with using the commercial Qubit dsDNA HS (Life) kit Technologies, USA). The genome of the measles virus was sequenced on an automatic genetic analyzer Genetic Analyzer 3500 (Applied Biosystems, USA) using the commercial Big Dye Terminator Kit V3.1 (Applied Biosystems, USA). The sequencing products were cleaned using the Big Dye $X$ Terminator Kit (Applied Biosystems, USA) in accordance with the manufacturer's instructions.

\section{Phylogenetic Analysis}

The nucleotide sequences of the $\mathrm{C}$ - terminal fragment of the $\mathrm{N}$-gene with a length of 450 nucleotides of the studiedsamples were compared with the sequences of the reference strains of the measles virus genotypes presented in the MeaNS database. The analysis of the nucleotide and corresponding amino acid sequences, multiple alignment was performed using the MEGA7 software. The phylogenetic tree was constructed using the "Neighbor - Joining" method of the MEGA6 program. The statistical reliability of clustering was evaluated using the "multiple repeats" method (bootstrap analysis, 500 repeats). For analysis, the first $10-15 \mathrm{ml}$ of the freely released first portion of morning urine is collected in a 50 $\mathrm{ml}$ disposable container. The lid of the container must be tightly screwed; the container must be marked. If it is not possible to collect morning urine, it should be collected urinate no earlier than 2 hours after the last urination. Storage conditions: at a temperature of $2-8^{\circ} \mathrm{C}$ - during the day.

\section{Conclusion}

Timely monitoring of suspected measles cases using highly sensitive and specific molecular diagnostic tools, combined with the genetic characteristics of isolates, is of paramount importance for global measles eradication efforts. In conclusion, this study showed that conducting molecular analyses of the measles virus provided important information to track the path of transmission, the origin of the infection, 


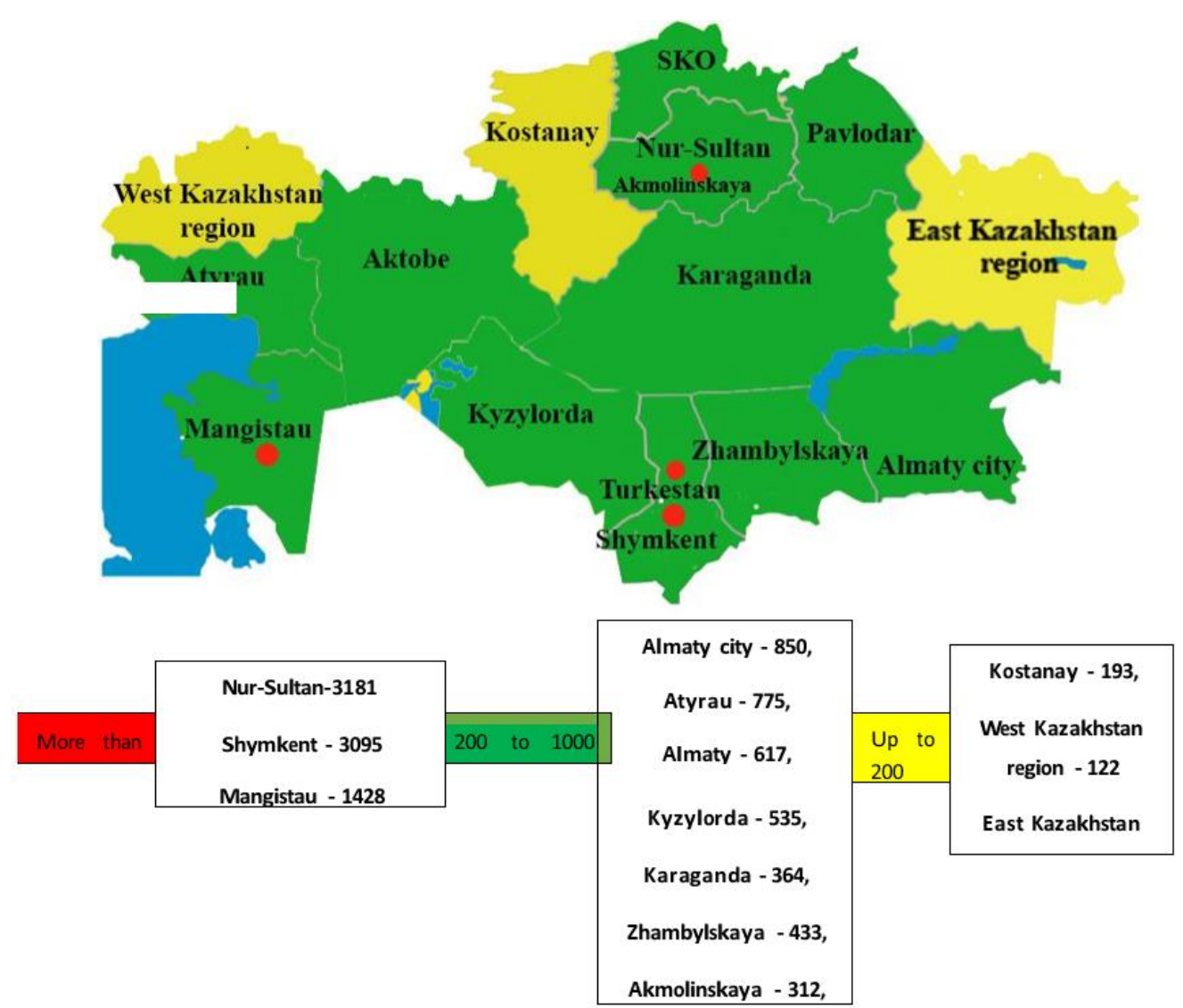

Figure 3. The incidence of measles in the Republic of Kazakhstan since November 2018 to December 2019

and the effectiveness of the desired vaccination. Genotyping of measles virus isolates is an important component of measles.

\section{RESULTS}

In this study, we studied the genetic characteristics of measles virus strains that were circulating in Kazakhstan during the 2018 outbreak.

In the Republic of Kazakhstan, the measles incidence rate per 100,000 people was $3.15 \%$, and in 2019 , the number of measles cases increased sharply and amounted to $71.97 \%$. Monitoring of the disease in the Republic of Kazakhstan indicated that the incidence of measles from November 2018 to December 30, 2019 amounted to 13,873 cases, $71.2 \%$ $(n=9,875)$ of which were children aged 6 monthsto 14 years. The incidence resulted in outbreaksin 4regions of the country, where the number of cases exceeded 1,000 patients: NurSultan (22.9\%; $n=3,181)$, Shymkent (22.3\%; $n=3,095)$, Mangistau (10.3\%; $n=1,428)$ and the Turkestan region ( $8 \%$ $(n=1,110)$. Cases of measles ranged from 200 to 1000 in Atyrau, Almaty, Kyzylorda, Karaganda, Zhambyl, Akmola, Aktobe, the North Kazakhstan region, the Pavlodar region, and Almaty city, and up to 200 cases are registered in Kostanay, as well as in West and East Kazakhstan regions (Figure 3).

Genotyping of viruses isolated from measles patients from different regions allows us to track the measlesviruscirculation and itsgenetic variation, identify endemic strains, confirm 223 the cessation of their circulation, and differentiate imported cases.

Genotyping by sequencing ( $\mathrm{N}-450)$ is a generally accepted method according to the WHO for identifying new genotypes and for studying the characteristics of an outbreak in a given region [11]. In this study, we obtained full-length gene sequences for two variants of variant B3 and D8, which coincides with data from foreign researchers $[12,13]$.

To examine the molecular and genetic characteristics of measles viruses, biological material (urine, $n=132$ ) from laboratory-confirmed cases was analyzed in the Reference Laboratory for the Control of Viral Infections of the Scientific and Practical Center for Sanitary and Epidemiological Expertise and Monitoring Branch of the Republican State Pedagogical Center at the Scientific and Practical Center for Health and Safety Ministry of Health of the Republic of Kazakhstan (Table 1).

According to the genotyping analysis, measles virus strains ( $n=18$ strains) isolated in the Republic of Kazakhstan in 2018 belong to two variants:

- Variant D8 (9 detections), composed of three genetic lines, "MVs/Frankfurt Main.DEU/17.11/[D8]" (1 detection), "MVs/Osaka.JPN/29.15/[D8]" (240 detections), and “MVs/Gir Somnath.IND/42.16/[D8]" (4 detections).

- Variant B3 (9 detections), composed of two genetic lines, "MVs/Dublin.IRL/8.6/[B3]" (2 detections) and 243 “MVs/Kabul.AFG/20.14/[B3]" (7 detections) (Figure 4).

\section{Variant B3}

When comparing the nucleotide sequence of nine strains with the nucleotide sequences of reference strains of variant B3, we observed the following:

- Two strains from Akmola (MVs/AkmolaCity.KAZ/16.18/) and Zhambyl (MVs/JambylCity.KAZ/34.18/) regions were nearly identical to the strain of variant B3 of the genetic line "MVs/Dublin.IRL/8.16/". 
Table 1. Clinical samples (urine) for molecular and genetic analysis of measles viruses, 2018

\begin{tabular}{|c|c|c|c|c|c|}
\hline Regions & $\begin{array}{l}\text { Abs. number of laboratory- } \\
\text { confirmed cases }\end{array}$ & $\begin{array}{c}\text { Amount of materials } \\
\text { received (urine) }\end{array}$ & $\begin{array}{c}\text { Taken for the } \\
\text { study }\end{array}$ & Prosecuted & Result \\
\hline Akmola & 32 & 21 & 2 & 2 & D8, B3 \\
\hline Aktobe & 1 & 1 & - & - & - \\
\hline Almaty & 12 & 9 & 2 & 1 & D8 \\
\hline Atyrau & 0 & 0 & - & - & - \\
\hline East Kazakhstan Region & 1 & 1 & - & - & - \\
\hline Zhambyl & 4 & 4 & 3 & 2 & D8, B3 \\
\hline West Kazakhstan Region & 0 & 0 & & & \\
\hline Karaganda & 15 & 1 & 1 & 1 & B3 \\
\hline Kostanay & 0 & 0 & - & - & - \\
\hline Kyzylorda & 0 & 0 & - & - & - \\
\hline Mangistau & 6 & 1 & - & - & - \\
\hline Pavlodar & 1 & 0 & - & - & - \\
\hline North Kazakhstan Region & 1 & 1 & 1 & 0 & 0 \\
\hline Turkestan & 28 & 16 & 1 & 1 & D8 \\
\hline Almaty city & 56 & 53 & 11 & 6 & $\mathrm{D} 8, \mathrm{~B} 3$ \\
\hline Astana city & 419 & 24 & 7 & 5 & B3 \\
\hline Total & 576 & 132 & 28 & 18 & \\
\hline
\end{tabular}

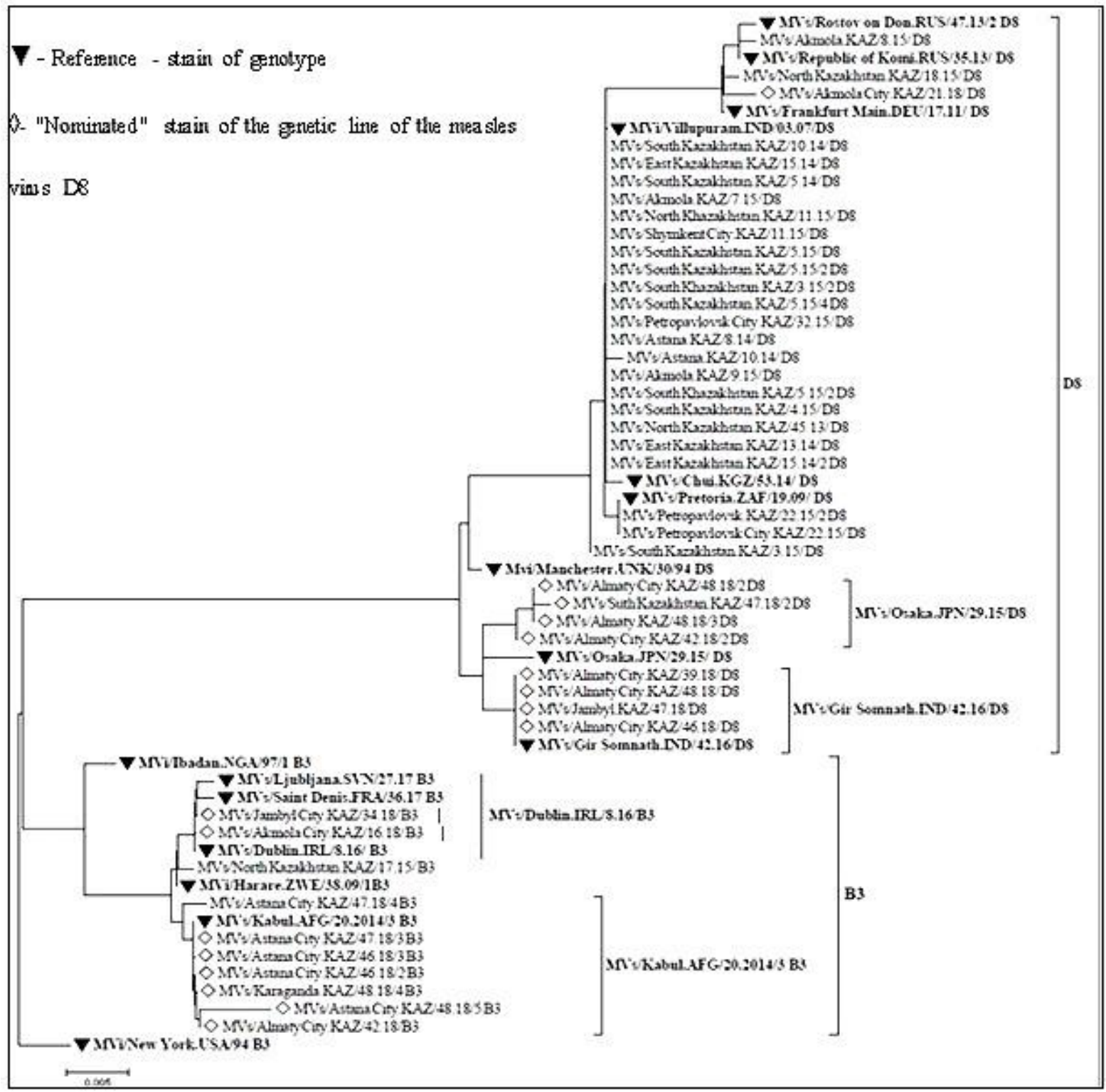

Figure 4. Phylogenetic tree of measles virus strains isolated in the Republic of Kazakhstan in 2018 and closely related strains (MeaNS database) 
- Seven strains from the Karaganda region (1 detection), Almaty (1 detection) and Astana (5 detections) showed 99\% homology with strains of variant B3 of the genetic line "MVs/Kabul.AFG/20.14/".

Variant B3 is endemic to countries in West Africa. In addition, local measles outbreaks and sporadic cases imported from Africa are regularly recorded in Western Europe [14]. Highlighted genetic lines of variant B3 in the Republic of Kazakhstan in 2018 that were previously reported in Kazakhstan did not stand out.

The strain of the genetic line "MVs/Dublin.IRL/8.16/", first isolated in Ireland (8 weeks 2016), was characterized by wide circulation in a number of countries in the WHO European Region during 2016 - 2018 (Ireland, Italy, Romania, Belgium, France, Great Britain, occasionally isolated in Germany, Portugal, Spain, Serbia, Switzerland, Sweden, Austria, and Finland). In the Russian Federation, a strain of this line was actively circulating in Moscow (June 2017 - January 2018), from where it was likely brought to other regions of Russia [15] and Kazakhstan.

The genetic line "MVs/Kabul. AFG/20.14/" of variant B3, first isolated in Afghanistan in 2014. This genetic line “MVs/Kabul.AFG/20.14/" caused an outbreak of the disease in the Odessa region of Ukraine, affecting more than 47 thousand people in 2018.

\section{Variant D8}

Analysis of the nucleotide sequence of nine strains with the nucleotide sequences of reference and reference strains of variant D8 revealed the following:

- 4 strains from Almaty (1 detection), Turkestan (1 detection) regions and Almaty city (2 detections) were nearly identical to the genetic strain line "MVs/Osaka.JPN/29.15/".

- 4 strains from Zhambyl oblast (1 detection) and Almaty city (3 detections) were closely related to the strain of the genetic line “MVs/Gir279Somnath.IND/42.16/". Indigenous transmission of strains of this genetic line 280 is observed in India.

- 1 strain from the Akmola region was identical to the strain of the genetic line "MVs/FrankfurtMain.DEU/17.11". The strain of the genetic line "MVs/Osaka.JPN/29.15/" was first isolated in Japan (2015) from a case of measles imported from Indonesia. Strains of this line were reinsulated in Japan during 2015 - 2017 and 2016 - 2017 and circulated in Australia (imported to Indonesia, Thailand, and Italy). Some cases and outbreaks of measles associated with the circulation ofstrains of this line were recorded in 2016-2018 in Austria, Denmark, France, Germany, the Netherlands, Spain, Switzerland, Sweden, USA, Malaysia, South Korea, Singapore, South Africa, and the Russian Federation.

The genetic line D8 “MVs/Frankfurt Main.DEU/17.11/" was allocated in Frankfurt am Main (Germany) in 2011, actively circulating in countries of the WHO European Region (Germany, Great Britain, Spain, France, Italy, Romania, Sweden, Denmark, Poland, Netherlands, Portugal, Serbia, Macedonia, Austria, Switzerland, Bulgaria, Ireland, Turkey, and Georgia) have occasionally been isolated in other countries (USA, Canada, Japan, Vietnam, and Australia). In Russia, repeated importation of strains of this genetic line was observed during 2013 - 2018 from countries in the WHO European Region [16,17]. Analysis of the N-450 sequence showed that cases of the B3 measles genotype were associated with the named strains MVs/Dublin.IRL/8.16/, MVs/Kabul.AFG/20.14/3, and MVs/Kansas.USA/1.12/. Cases of D8 measles are derived from Mvi/cHuluLangat.Weare from/26.11/, MVS/Osaka.Japan/29.15/, and MVC/Victoria. Steelaus/6.11/. The sequences are identical to others described in Afghanistan, Bangladesh, Cambodia, Dubai, Germany, India, Italy, Myanmar, Romania, Somalia, and Thailand. The indicated genetic lines of the measles virus D8 variant were not previously circulated in the Republic of Kazakhstan; in this case, there was an independent import of infection.

\section{DISCUSSION}

One of the important points of the implementation of the measles elimination action plan in the Republic of Kazakhstan is the additional immunization program and molecular genetic characterization of strains of the measles virus in order to monitor their circulation among the population, as an important element of epidemiological surveillance. In the Republic of Kazakhstan, according to the national vaccination calendar, since 2006, the CCP vaccine has been introduced in 12 months, taking into account the unfavorable epidemiological situation for measles in the world - since April 1, 2019, an additional program of immunization of the population has begun in the republic. The vaccination program includes children who have reached the age of nine months, persons under 30 years of age with an unknown vaccination status, who have not been vaccinated before and have not had measles, who were vaccinated five or more years ago with one measles vaccination in the foci of infection, as well as medical workers.

Genotyping of virus strains is particularly important when the elimination phase is reached, since only virological monitoring allows documenting the interruption of transmission of previously endemic genotypes, which is one of the main indicators of elimination.

Molecular genetic studies of samples isolated from measles patients in different regions allow usto track the circulation of themeaslesvirusand itsgenetic variability, identify endemic strains, confirm the cessation of their circulation, differentiate imported cases, investigate unusual casesof diseases, as well asto establish links, track the path of transmission. The newly created "Means" database ("Measures Nucleotide Surveillance") allows its users to share information about sequences and automatically upload this information to WHO databases. Most genotypes have a certain geographical distribution, which allows monitoring their circulation $[18,19]$.

\section{CONCLUSIONS}

As part of our study, it was found that measles viruses were detected in genotypes B3 and D8 obtained as a result of the study of 20 cases of the disease. With the help of this study, viruses of genotypes B3 and D8 were first detected in Kazakhstan during the outbreak. The fact that this genotype shows 99\% sequence homology to B3 viruses found in countries such as Ireland, Italy, Romania, Belgium, France, Great Britain, Germany, Portugal, Spain, Serbia, Switzerland, Sweden, Austria, Finland, and D8 genotype viruses found in 
Table 2. Sources of independent episodes of infection importation

\begin{tabular}{|c|c|c|c|c|c|}
\hline $\begin{array}{l}\text { Genotype-the } \\
\text { identification } \\
\text { number of a } \\
\text { specific sequence } \\
\text { in MeaNS }\end{array}$ & $\begin{array}{l}\text { Name of the affected area } \\
\text { (national level or list of } \\
\text { affected subnational } \\
\text { territories) }\end{array}$ & $\begin{array}{l}\text { Total number of } \\
\text { cases in } 2018\end{array}$ & $\begin{array}{l}\text { Duration (date of onset } \\
\text { of the disease of the } \\
\text { first case, date of onset } \\
\text { of the disease of the } \\
\text { last case; or "outbreak } \\
\text { continues") }\end{array}$ & $\begin{array}{l}\text { Documentary } \\
\text { evidence that the } \\
\text { first case is imported } \\
\text { (yes/no) }\end{array}$ & $\begin{array}{l}\text { Are there sporadic cases } \\
\text { of the same origin that } \\
\text { are not part of the } \\
\text { identified outbreak/chain } \\
\text { of transmission? How } \\
\text { many cases? Dates of } \\
\text { occurrence of the first } \\
\text { and last sporadic cases }\end{array}$ \\
\hline MEA-KAZ-2018-01 & $\begin{array}{c}\text { Kokshetau city, Akmola and } \\
\text { Zhambyl regions (B3- } \\
\text { Vs/Dublin.IR/8.16) }\end{array}$ & $\begin{array}{l}31 / 3 \\
\text { respectively, in } 2 \\
\text { areas=34 }\end{array}$ & 13.04.18-31.12.18 & $\begin{array}{c}\text { Yes } \\
\text { Arrived, from Russia } \\
\text { for } 2 \text { months (North } \\
\text { Ossetia, arrived } \\
\text { 09.04.2018 got sick } \\
\text { 13.04.2018) }\end{array}$ & $\begin{array}{c}1 \text { case ((D8-Vs/Frankfurt } \\
\text { Main.Deu/17.11/) } \\
\text { The child fell ill on } \\
21.03 .18, \text { was in contact } \\
\text { with the mother living in } \\
\text { Astana in } 2018, \text { who went } \\
\text { to Turkey in early March }\end{array}$ \\
\hline MEA-KAZ-2018-02 & $\begin{array}{c}\text { Almaty city (D8- } \\
\text { Vs/GirSomnath.IND/42.16) }\end{array}$ & 27 & $\begin{array}{l}\text { 19.09.18r. } \\
\text { The outbreak continues }\end{array}$ & Yes & \\
\hline MEA-KAZ-2018-03 & $\begin{array}{c}\text { Almaty and Astana cities; } \\
\text { Karaganda, Mangistau, } \\
\text { North Kazakhstan regions } \\
\text { (B3-MVs/Kabul.AFG/ } \\
\text { 20.2014/3) }\end{array}$ & $\begin{array}{c}18 / 419 / 15 / 6 / 1 \\
\text { Total }^{*} 459\end{array}$ & $\begin{array}{l}\text { 09.10.18r. } \\
\text { The outbreak continues }\end{array}$ & Yes & \\
\hline \multirow[t]{2}{*}{ MEA-KAZ-2018-04 } & $\begin{array}{c}\text { Almaty city, Turkestan } \\
\text { region } \\
\text { (D8-MVs/Osaka.JPN/29.15/) }\end{array}$ & $11 / 9=20$ & $\begin{array}{l}12.10 .18 \mathrm{r} \text {. } \\
\text { The outbreak continues }\end{array}$ & Yes & 1 \\
\hline & $\begin{array}{c}\text { Total number of cases in } \\
\text { outbreaks/transmission } \\
\text { chains }\end{array}$ & 540 & & $\begin{array}{l}\text { SUM-the total number } \\
\text { of sporadic cases with } \\
\text { a specific genotype }\end{array}$ & \\
\hline MEA-KAZ-2018-02 & $\begin{array}{c}\text { Almaty city (D8-MVs/Gir } \\
\text { Somnath.IND/42. 16) }\end{array}$ & 27 & $\begin{array}{c}\text { 19.09.18r. } \\
\text { The outbreak continues }\end{array}$ & Yes & \\
\hline
\end{tabular}

countries such as Austria, Denmark, France, Germany, the Netherlands, Spain, Switzerland, Sweden, the United States, Malaysia, South Korea, Singapore, South Africa and the Russian Federation indicates that the outbreak occurred with viruses imported from these countries. Thus, genotyping data indicate the presence in the Republic of Kazakhstan in 2018 of at least 5 independent episodes of infection importation from abroad from different sources (Table 2).

Timely monitoring of suspected measles cases using highly sensitive and specific molecular diagnostic tools, combined with the genetic characteristics of isolates, is of paramount importance for global measles eradication efforts.

Author contributions: All authors have sufficiently contributed to the study, and agreed with the results and conclusions.

Funding: Financial support for this study was carried out through a system of scientific grants AP05135073, AP05134659, and AP05132694 of the Ministry of Education and Science of the Republic of Kazakhstan. Acknowledgement: The authors express their gratitude for the advisory assistance in writing the article to the 340 head of the reference laboratory "Center for Sanitary and Epidemiological Expertise and Monitoring" of the RSE at the PCV "NKPH" Tleumbetova N. Zh.

Declaration of interest: No conflict of interest is declared by authors.

\section{REFERENCES}

1. Santibanez S, Hübschen JM, Ben Mamou MC, et al. Molecular surveillance of measles and rubella in the WHO European region: new challenges in the elimination phase. Clin Microbiol Infect. 2017;23(8):516-23. https://doi.org/ 10.1016/j.cmi.2017.06.030 PMid:28712666
2. Shanks GD, Hu Z, Waller M, et al. Measles epidemics of variable lethality in the early 20 th century. Am J Epidemiol. 2014;179(4):413-22. https://doi.org/10.1093/aje/kwt282 PMid:24284015

3. Holzmann $\mathrm{H}$, Hengel $\mathrm{H}$, Tenbusch M, Doerr HW. Eradication of measles: remaining challenges. Med Microbiol Immunol. 2016;205(3):201-8. https://doi.org/10.1007/s00430-0160451-4 PMid:26935826 PMCid:PMC4866980

4. Measles vaccines: WHO position paper - April 2017. Wkly Epidemiol Rec. 2017;92(17):205-27. PMid:28459148

5. O'Connor P, Jankovic D, Muscat $M$, et al. Measles and rubella elimination in the WHO region for Europe: progress and challenges. Clin Microbiol Infect. 2017;23(8):504-10. https://doi.org/10.1016/j.cmi.2017.01.003 PMid:28111293 PMCid:PMC6434680

6. Patel MK, Gacic-Dobo M, Strebel PM, et al. Progress toward regional measles elimination - worldwide, 2000 - 2015. MMWR Morb Mortal Wkly Rep. 2016;65(44):1228-33. https://doi.org/10.15585/mmwr.mm6544a6 PMid: 27832050

7. Durrheim DN, Crowcroft NS, Strebel PM. Measles - the epidemiology of elimination. Vaccine. 2014;32(51):6880-3. https://doi.org/10.1016/S2214-109X(20)30002-4 PMid: 25444814

8. World Health Organization. Measles in Europe: record number of both sick and immunized. Geneva: Workd Health Organization; 2019. Available at: https://www.who.int/ news-room/fact-sheets/detail/measles

9. Coughlin MM, Beck AS, Bankamp B, Rota PA. Perspective on global measles epidemiology and control and the role of novel vaccination strategies. Viruses. 2017;9(1):11. https://doi.org/10.3390/v9010011 PMid:28106841 PMCid: PMC5294980 
10. World Health Organization. Measles fact sheet. Geneva: World Health Organization; 2016. Available at: https://www.euro.who.int/data/assets/pdf_file/0007/2763 79/Factsheet-Measles-en.pdf

11. Guidelines for the laboratory diagnosis of measles and rubella. 2010. Available at: https://www.who.int/ihr/ elibrary/manual_diagn_lab_mea_rub_en.pdf

12. Ciceri G, Canuti M, Bianchi S, et al. Genetic variability of the measles virus hemagglutinin gene in B3 genotype strains circulating in Northern Italy. Infect Genet Evol. 2019;75:103943. https://doi.org/10.1016/j.meegid.2019. 103943 PMid:31255832

13. Lüthy IA, Kantor IN. Sarampión [Measles]. Medicina (B Aires). 2020;80(2):162-8. PMid:32282323

14. Mina MJ, Kula $T$, Leng $Y$, et al. Measles virus infection diminishes preexisting antibodies that offer protection from other pathogens. Science. 2019;366(6465):599-606. https://doi.org/10.1126/science.aay6485 PMid:31672891
15. Su Q-R, Yao K-H. [Epidemiological and clinical features of vaccine-preventable diseases in vaccine era]. Zhongguo Dang Dai Er Ke Za Zhi. 2019;21(3):195-8. https://doi.org/ 10.7499/j.issn.1008-8830.2019.03.001 PMid:30907338 PMCid:PMC7389355

16. Measles virus nomenclature update: 2012. Wkly Epidemiol Rec. 2012;87(9):73-81. PMid:22462199

17. Muñoz-Alía MÁ, Fernández-Muñoz R, Casasnovas JM, et al. Measles virus genetic evolution throughout an imported epidemic outbreak in a highly vaccinated population. Virus Res. 2015;196:122-7. https://doi.org/10.1016/j.virusres. 2014.11.015 PMid:25445338

18. Database MeaNS. Available at: http://www.whomeasles.org/Public/Web_Front/main.php

19. ECDC Internal Decision. Risk of measles transmission in the EU/EEA 23 March 2018. Available at: https://www. ecdc.europa.eu/sites/default/files/documents/Measlesrapid-risk-assessment-European-Union-countries_0.pdf 